\title{
Traditional use of slow lorises Nycticebus bengalensis and $N$. pygmaeus in Cambodia: an impediment to their conservation
}

\author{
Carly Starr $^{1, *}$, K. A. I. Nekaris ${ }^{2}$, Ulrike Streicher ${ }^{3}$, Luke Leung $^{1}$ \\ ${ }^{1}$ School of Animal Studies, University of Queensland, Gatton Campus, Queensland 4343, Australia \\ ${ }^{2}$ Oxford Brookes University, Nocturnal Primate Research Group, School of Social Sciences and Law, Oxford OX3 0BP, UK \\ ${ }^{3}$ Wildlife Rescue Programme, Nam Theun 2 Hydropower Project, Nakai, Laos
}

\begin{abstract}
In Cambodia, periodic reports since the 1990s have identified the sale of large numbers of dried pygmy Nycticebus pygmaeus and northern slow lorises $N$. bengalensis in traditional medicine stores. We used interviews and questionnaires to identify the uses and users of lorises, elucidate factors affecting selection of loris medicines, and determine whether access to alternative therapies may reduce the use of loris medicines. Pygmy lorises were found to be the most commonly requested animal from traditional medicine stores in Cambodia's capital Phnom Penh, and the primary users recalled by sellers were women between the ages of 25 and 45 from middle to upper class backgrounds. Slow lorises were predominantly used in a tonic for women after childbirth, stomach problems, healing wounds and broken bones, and in the treatment of sexually transmitted diseases. Lorises were reported to be sourced from provinces with large protected areas within their distribution ranges. Market values of both species more than doubled from 1997 to 2007; however, the majority of respondents expressed reluctance to substitute loris medicines with alternatives, indicating that promotion of alternatives would be an inappropriate conservation tool. Education and enhanced law enforcement are vital to conserve slow lorises in Cambodia.
\end{abstract}

KEY WORDS: Slow loris $\cdot$ Wildlife trade $\cdot$ Interview $\cdot$ Cambodia $\cdot$ Conservation

\section{INTRODUCTION}

Mammals in Asia have been hunted for at least $40000 \mathrm{yr}$; in the last $50 \mathrm{yr}$, however, this practice has become increasingly unsustainable (Corlett 2007). Over-exploitation now poses one of the greatest threats to wildlife in the region (Cheung \& Dudgeon 2006), due to greater demand, increased value of wildlife in markets and decreasing supply (Robertson et al. 2004). Throughout Southeast Asia, hunting is no longer carried out solely for subsistence, and wealth in urban areas is replacing poverty in rural areas as a drive for the capture of wild animals (Corlett 2007).

Eleven species of primates are currently known to occur in Cambodia (Rawson \& Roos 2008), and the World Bank (WB) identified the country as a primary source country for trade in wild primates in the Greater Mekong Subregion (WB 2005). Two species of slow loris occur in the country: the pygmy loris Nycticebus pygmaeus and the northern (also known as ashy or Bengal) slow loris $N$. bengalensis.

Slow lorises are among the most commonly observed protected primates for sale in marketplaces across their distribution ranges (Nekaris \& Nijman 2007) and have long been used in traditional medicines, with reports dating back to 1900 (Ridley 1900). In Cambodia, dried lorises have been seen in large numbers for sale in marketplaces throughout the country, particularly in the 1990s (Baird 1993, Martin \& Phipps 1996, Stich \& Krüger 2002, S. Broad unpubl.), with as many as 204 specimens being recorded in a single market store (M. Bezuijen unpubl.). A programme run 
by the Cambodian Forestry Administration (FA) and the Wildlife Alliance-Cambodia confiscated 277 slow lorises from 2002 to 2009 and reported lorises as one of the mammal taxa most commonly confiscated by their enforcement unit (N. Marx pers. comm.). Recent surveys by the wildlife trade monitoring network TRAFFIC also found lorises in nearly all rural markets assessed in Cambodia (Walston 2005). In June 2007, slow lorises were transferred from Appendix II of the Convention on International Trade in Endangered Species of Wild Fauna and Flora (CITES) to Appendix I in an attempt to curb illegal international trade (Nekaris \& Nijman 2007).

The WB invested over 310 million US dollars (USD) in East and Southeast Asia on biodiversity conservation from 2000 to 2005; a recent report, however, identified that success in these programmes is seriously compromised by the illegal wildlife trade (WB 2005). They suggest that failure to address this problem may be an impediment to future funding (WB 2005).

Little is known about the ecological, cultural and economic factors affecting the use of wildlife in traditional medicines. Such knowledge would be useful for developing improved strategies with which to mitigate trade (Alves \& Rosa 2005). We describe the use of loris species in traditional medicine in Cambodia, identify the users, elucidate factors affecting the choice of loris species for medicinal use, and determine whether there is any scope to reduce the use of lorises within the country.

\section{METHODS}

Questionnaires. Preliminary open-ended interviews were conducted with 7 traditional medicine doctors from the National Centre for Traditional Medicine (NCTM) and the Association for Traditional Medicines (ATM) in Phnom Penh (Fig. 1), on 15 and 16 March 2007. Traditional medicine doctors identified sellers of traditional medicines in Cambodia as a knowledgeable demographic from whom we could collect the data we required; such sellers often function in the same way a 'pharmacist' may in Western medicines, providing advice on the use of products. Findings from these initial interviews were used to develop the questionnaires. We conducted 111 dichotomous, multichotomous and scale-response closed-answer questionnaires with traditional medicine sellers in Phnom Penh between May and July 2007. Non-random sampling methods were used, as the aim was to interview as many sellers as could be located. Sellers were located ad hoc, by actively searching for traditional medicine stores, and by word of mouth through other traditional medicine vendors. Sellers with at least $10 \mathrm{yr}$ of experi-

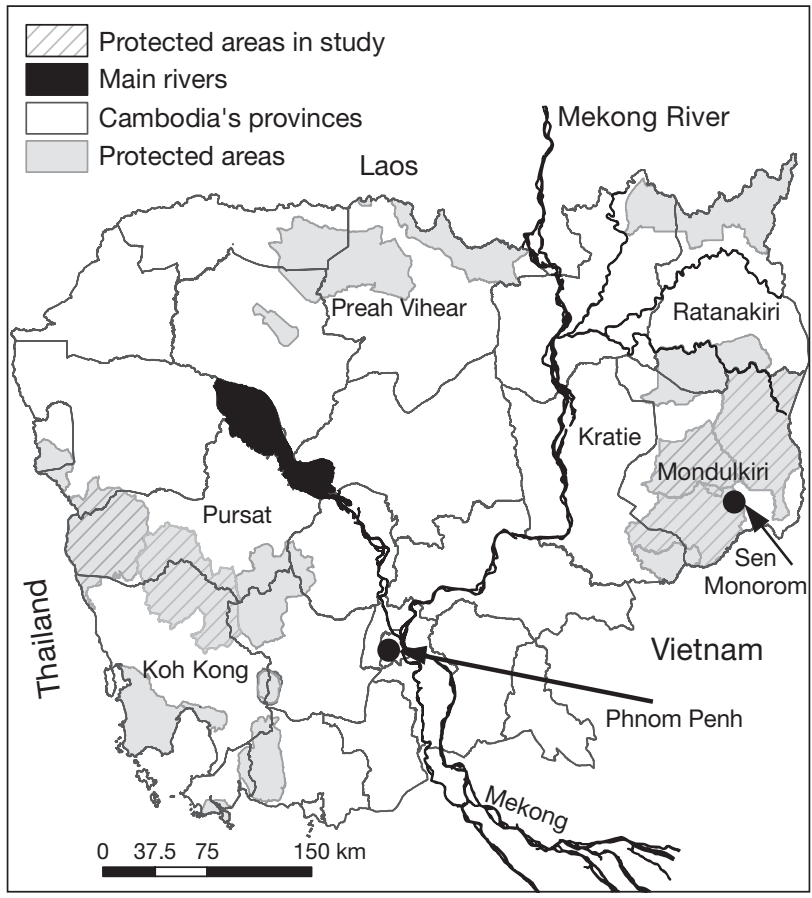

Fig. 1. Study sites in Cambodia, also showing Phnom Penh, and Sen Monorom, where a large wildlife market is located. Interviews were conducted in the highlighted protected areas. Pygmy lorises occur east of the Mekong River, which dissects the country, and the northern slow loris is currently only recorded west of the Mekong in Cambodia

ence in selling traditional medicines were asked to give estimated values of animals and price changes over this 10 yr period. Data were collected in Cambodian Riel (KHR) and were adjusted for inflation to 2007 levels using the Consumer Price Index for Cambodia, sourced from the International Monetary Fund (www. imf.org/external/index.htm). Adjusted prices were then converted to USD at the exchange rate on 1 June 2007 (4068 KHR = 1 USD), sourced from the National Bank of Cambodia (www.nbc.org.kh).

The order in which questions were asked had rotational points to prevent bias arising, and double translations were conducted to ensure accuracy. Questionnaires were always started by asking which animals were used in traditional medicine, loris-specific questions were asked subsequently. Two Cambodian students in the final year of environmental science from the Royal University of Phnom Penh were employed to conduct the interviews. Opportunistic observations of dried lorises throughout Cambodia for 2007 and 2008 were also recorded.

Open-ended interviews were conducted with local people in 2007 and 2008 in Mondulkiri, Pursat and Koh Kong Provinces whilst conducting field surveys (Starr et al. 2010, in press). We interviewed 44 people about 
the local use and sale price of pygmy lorises in and bordering Mondulkiri Protected Forest, Seima Biodiversity Conservation Area and Phnom Prich Wildlife Sanctuary, the 3 largest protected landscapes in Mondulkiri Province (Fig. 1). Sixteen interviews were conducted in Promoay and O'som townships, Phnom Samkos Wildlife Sanctuary, Pursat Province and Thma Bang, Central Cardamom Mountains, Koh Kong Province, where the northern slow loris is known to occur. Participants included traditional medicine doctors $(\mathrm{n}=6)$, health workers $(\mathrm{n}=2)$, park protection staff $(\mathrm{n}=27)$, taxi drivers at a popular wildlife market in the provincial capital Sen Monorom $(n=5)$ and ex-loris hunters and traders $(\mathrm{n}=20)$.

Data analysis. Descriptive statistics were conducted where possible. Response frequencies are presented as percentages, and given in the 'Results' as $x \%, y / z$, where $y=$ the number of participants who gave the response, and $z=$ the total number of participants who were asked the question. This method was used as not all participants answered each question, and new questions were added during the course of the study, based on early findings.

\section{RESULTS}

\section{Interviews conducted in Phnom Penh}

Age groups of the 111 participants were distributed as follows: $18-25 \mathrm{yr}(1.8 \% ; \mathrm{n}=2), 26-35 \mathrm{yr}(28.8 \% ; \mathrm{n}=$ $32), 36-45 \mathrm{yr}(51.4 \% ; \mathrm{n}=57), 46-55 \mathrm{yr}(16.2 \% ; \mathrm{n}=18)$ and $>50$ yr $(1.8 \%, n=2)$. Sixty males and 51 females participated in the questionnaire.

Lorises were the most frequently requested wildlife by buyers from traditional medicine sellers $(84.68 \%$, 94/111). Other animals included snakes $(31.13 \%$, $35 / 111)$, pangolins $(18.01 \%, 20 / 111)$, small cats $(14.41 \%, 16 / 111)$ and frogs/toads $(12.61 \%, 14 / 111)$.

Buyers primarily purchased lorises for use in traditional medicines $(96.38 \%, 61 / 62)$. Some sellers also thought lorises might be kept as pets $(48.39 \%, \mathrm{n}=$ $30 / 62$ ), but they had not observed this in Cambodia. Two traditional medicine practitioners from the NCTM reported that sometimes animals are roasted alive, as it is believed this might increase the potency of the medicine. Dried lorises were made into pre-mixed medicines by sellers, which often included honey and charcoal, e.g. ointments (Fig. 2) and tablets.

Nearly all sellers reported 2 distinct types of lorises used in traditional medicines $(83.7 \%, 41 / 49)$. Descriptions provided by sellers of a smaller, red loris matched that of the pygmy loris, and a larger, grey species matched that of the northern slow loris. Pygmy lorises were reported as easier to source by sellers, more potent, and sold more commonly than the northern slow loris $(75 \%, 57 / 76)$.

More than half the sellers selected 'agree' when asked if there had been a shift from animals to plants used in Phnom Penh for traditional medicines in the past $5 \mathrm{yr}(54.5 \%, 24 / 44)$; however, some selected 'no change' $(29.5 \%, 13 / 44)$, 'strongly agree' $(13.6 \%, 6 / 44)$ and 'disagree' $(2.3 \%, 1 / 44)$. When asked if they thought loris medicines specifically were becoming more or less popular in Phnom Penh, most thought they were becoming 'more popular' $(42.6 \%, 20 / 47)$, although some participants believed they were becoming 'less popular' $(31.9,15 / 47)$ or that there was no change $(25.5 \%, 12 / 47)$.

Primary purchasers of loris medicines were women $(76 \%, 35 / 50)$, between the ages of 25 and $45(92 \%$, $35 / 50$ ), who were considered by sellers to be wealthy to middle class $(84.6 \%, 55 / 65)$. The majority of sellers thought the primary users were people who lived in urban areas $(50 \%, 20 / 40)$, with a small number identifying people from rural areas $(27.5 \%, 11 / 40)$ and indigenous minority people $(22.5 \%, 9 / 40)$.

Preliminary open-ended interviews with traditional medicine doctors from NCTM and with sellers identified that lorises are believed to have healing properties and are used for a large number of treatments. The primary ailments for which loris treatments were used were reported to be: for women after childbirth $(69 \%$, $77 / 111)$; stomach problems $(54.1 \%, 60 / 110)$; wounds $(54.1 \%, 60 / 111)$; broken bones $(53.2 \%, 59 / 111)$, and; sexually transmitted diseases $(16.2 \%, 18 / 111$; Table 1$)$.

When asked where someone from Phnom Penh would go to get a loris for medicine, sellers reported the best place would be a provincial market $(74 \%$, 37/50), followed by a marketplace in Phnom Penh $(32 \%, 16 / 50)$, traditional medicine sellers who operate from their own house $(30 \%, 15 / 50)$, traditional medicine doctors $(2 \%, 1 / 50) ; 1$ respondent reported that attempting to catch one from a nearby forest was the best method $(2 \%, 1 / 50)$. Sellers reported that Preah Vihear $(34 \%, 17 / 50)$, Kratie $(32 \%, 16 / 50)$ and Mondulkiri $(20 \%, 10 / 50)$ (Fig. 1) were where they would recommend customers purchase northern slow loris outside of Phnom Penh. To purchase a pygmy loris, they recommended Ratanakiri (70\%, 35/50), Mondulkiri (62\%, $31 / 50)$ and Kratie $(40 \%, 22 / 50$; Fig. 1). Participants reported that no lorises were traded from Phnom Penh to Vietnam, Thailand, China or Laos, and the use of loris was thought to be in-country. When asked if they knew which provinces lorises came from in Cambodia, the 3 most common responses for the pygmy loris were Ratanakiri $(70 \%, 35 / 50)$, Mondulkiri $(58 \%, 29 / 50)$ and Kratie (30\%, 15/50; Fig. 1); and for the northern slow loris: Preah Vihear $(52 \%, 26 / 50)$, Pursat $(26 \%, 13 / 50)$, and Kratie Provinces $(32 \%, 16 / 50)$. 

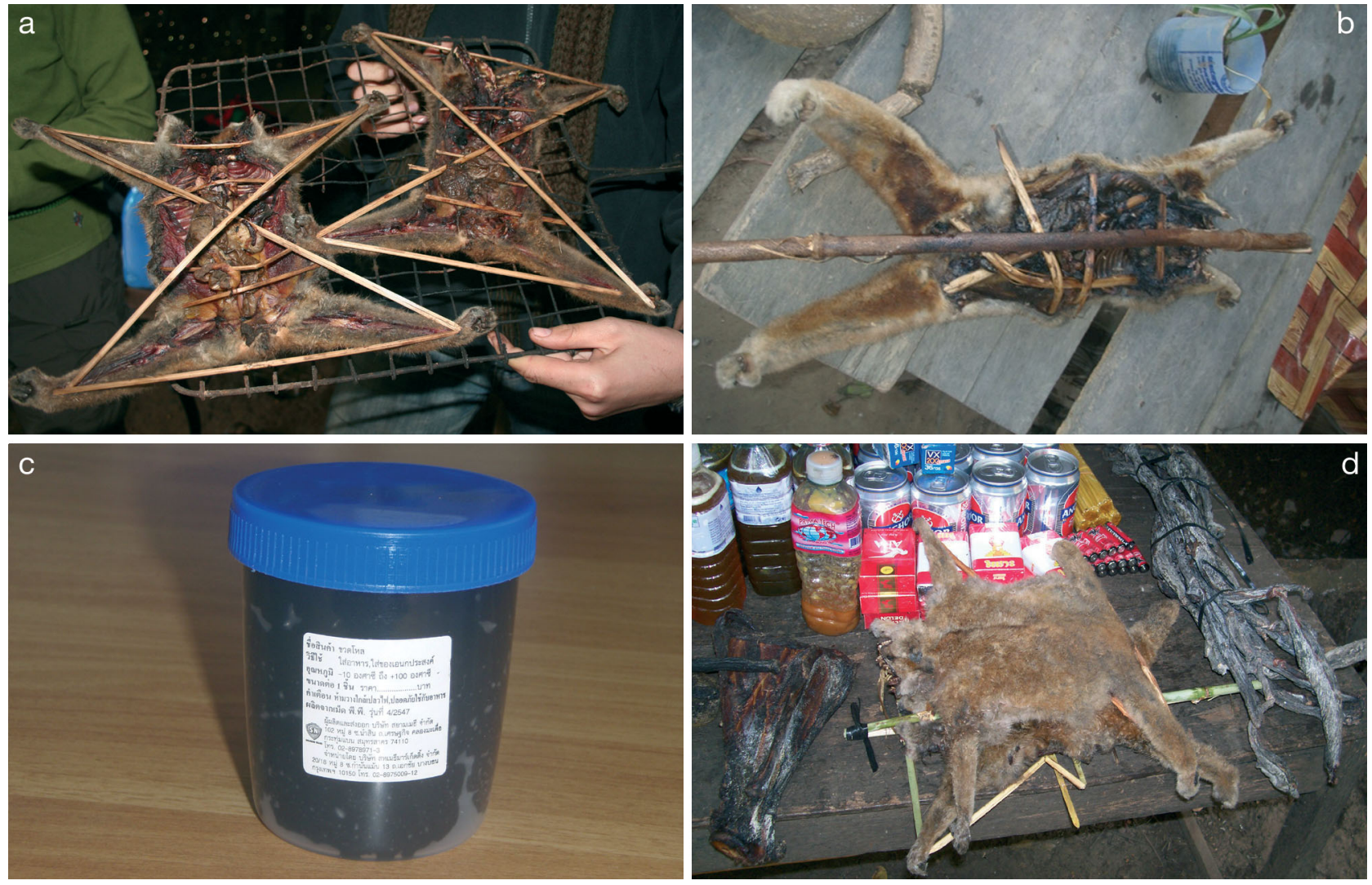

Fig. 2. Nycticebus pygmaeus and N. bengalensis. (a) Preparation of 2 pygmy lorises at a hunter's house in a village in the province of Mondulkiri (photo courtesy of C. Greenwood). (b) Preparation of a northern slow loris in Pursat Province (photo courtesy of F. Beattie). (c) Loris ointment available in Phnom Penh (photo by C. Starr). (d) Dried pygmy lorises for sale at Bousra market near Sen Monorom, Mondulkiri Province (photo by C. Starr)

Table 1. Percent of responses $(\mathrm{n}=46)$ regarding preferred treatments for ailments reported to be commonly treated by loris (Nycticebus pygmaeus and $N$. bengalensis) medicines. The highest percentages of responses for treatments are highlighted in bold

\begin{tabular}{|lcccc|}
\hline & $\begin{array}{c}\text { Plant-based } \\
\text { traditional } \\
\text { medicine }\end{array}$ & $\begin{array}{c}\text { Loris-based } \\
\text { traditional } \\
\text { medicine }\end{array}$ & $\begin{array}{c}\text { Western } \\
\text { medicine }\end{array}$ & $\begin{array}{c}\text { Other } \\
\text { medicine }\end{array}$ \\
\hline Childbirth & 6.5 & $\mathbf{6 7 . 4}$ & 15.2 & 10.9 \\
Stomach & 28.3 & $\mathbf{4 7 . 8}$ & 17.4 & 6.5 \\
Wounds & 28.2 & $\mathbf{4 5 . 7}$ & 17.4 & 8.7 \\
Broken bones & $\mathbf{4 3 . 5}$ & 4.3 & 26.1 & 26.1 \\
Muscle & $\mathbf{4 5 . 7}$ & 28.3 & 19.5 & 6.5 \\
$\begin{array}{l}\text { Sexually transm. } \\
\text { diseases }\end{array}$ & 39.1 & 2.2 & $\mathbf{5 0 . 0}$ & 8.7 \\
\hline
\end{tabular}

Increasing prices were reported by traditional medicine sellers for both species over the last 10 yr (Fig. 3). Sellers in Phnom Penh were questioned about the reasons for an increase in price over the past $12 \mathrm{mo}$, and more than $80 \%$ concurred that increased enforcement

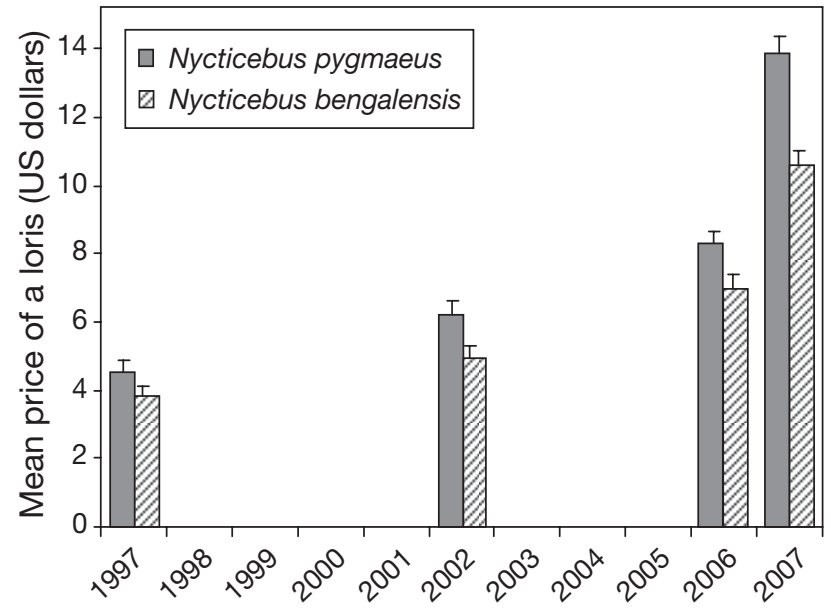

Fig. 3. Nycticebus pygmaeus and $N$. bengalensis. Mean price $( \pm \mathrm{SE})$ of 2 species of loris in Phnom Penh as recalled by traditional medicine sellers $(n=43)$ in 1997, 2002, 2006 and 2007 in US dollars (USD). Prices (in Cambodian Riel) were adjusted to account for inflation over the $10 \mathrm{yr}$ period, using 2007 as the base year. No data were collected for 1998-2001 and 2003-2005 
and decreasing numbers of lorises were the cause (Table 2). No seasonal differences were reported for the availability of lorises, and they can be purchased throughout the year. Sellers all believed that the sex or age of lorises was not important for traditional medicines. Both sexes and any aged loris would have the same medicinal qualities.

\section{Interviews conducted in the provinces}

Age groups of the 60 participants in Mondulkiri, Pursat and Koh Kong Provinces were: 18-25 yr (3.1\%), $26-35$ yr $(21.9 \%), 36-45$ yr $(32.8 \%), 46-55$ yr $(18.8 \%)$ and $>50 \mathrm{yr}(23.4 \%)$. All participants were male.

In Mondulkiri, the pygmy loris was reported to be used for women after childbirth $(63.6 \%, 28 / 44)$, wounds $(54.6 \%, 24 / 44)$, stomach problems $(34.1 \%$, $15 / 44)$, broken bones $(13.6 \%, 6 / 44)$ and other $(6.8 \%$, 3/44). All participants from Pramoay and O'som (Phnom Samkos Wildlife Sanctuary) reported that northern slow lorises were used for women after childbirth $(100 \%, 8 / 8)$. Participants from O'som reported that the gall bladder of lorises was historically used locally for ink in tattoos.

Prices of lorises in the provincial areas covered varied from USD 5 to $8.75(\mathrm{n}=60)$. The average price that hunters received for selling a pygmy loris locally was: USD 7.50 in Seima Biodiversity Conservation $(n=13)$, USD 5.00 in Phnom Prich Wildlife Sanctuary $(n=20)$ and USD 5.25 in Mondulkiri Protected Forest $(n=6)$. Interviewees all reported increasing prices in Mondulkiri, meaning that local people would often sell animals on to traders, rather than use them locally. Sellers at Bousra market, a popular tourist destination just out of Sen Monorom, Mondulkiri Province, sold pygmy lorises for an average price of USD $8.75(n=5)$. Interviewees reported that the mean price of purchasing a northern slow loris from a hunter was USD $5.00(n=16)$.

Interviews in Thmar Bang (Central Cardamom Protected Forest) indicated local extirpation of northern slow lorises. There had been no recent confiscations

Table 2. Percent of participants (number of respondents in parentheses; total $\mathrm{n}=46$ ) responding to statements about causal factors for the increase in price of loris (Nycticebus pygmaeus and N. bengalensis) medicines from 2006 to 2007 in Phnom Penh

\begin{tabular}{|lcccccc|}
\hline Statement & $\begin{array}{c}\text { Strongly } \\
\text { agree }\end{array}$ & Agree & $\begin{array}{c}\text { Neither agree } \\
\text { nor disagree }\end{array}$ & Disagree & $\begin{array}{c}\text { Strongly } \\
\text { disagree }\end{array}$ \\
\hline $\begin{array}{c}\text { Increased enforcement } \\
\text { in Phnom Penh }\end{array}$ & $\begin{array}{c}11 \\
(5)\end{array}$ & $\begin{array}{c}72 \\
(33)\end{array}$ & 0 & $\begin{array}{c}17 \\
(8)\end{array}$ & 0 \\
$\begin{array}{c}\text { Reduction in no. of } \\
\text { lorises in the forest }\end{array}$ & 39 & $\begin{array}{c}17 \\
(18)\end{array}$ & $(8)$ & $\begin{array}{c}43 \\
(20)\end{array}$ & 0 & 0 \\
\hline
\end{tabular}

of lorises by rangers, or reports in the community of recent use in traditional medicines. As in the other provinces, interviewees reported they were used in the past for women after childbirth. Local people believed that lorises might still be encountered deeper within the protected area. During the course of the study few opportunistic observations were made of northern slow lorises in marketplaces $(n=3)$; this is in contrast to the number of dried pygmy lorises encountered $(n=55)$.

\section{DISCUSSION}

Although sellers reported an overall shift from animals to plants as ingredients in traditional remedies, lorises were reported to be the most frequently requested wildlife product in Phnom Penh. The majority of participants thought the use of lorises was becoming more popular in Phnom Penh; however, we did not observe dried lorises in traditional medicine retail outlets in the capital. Users possibly purchase from provincial areas (where animals were observed in large numbers), or transactions are made more secretively in Phnom Penh due to more stringent enforcement initiatives.

Sellers demonstrated local knowledge about the taxonomy and distribution of loris species in Cambodia. The majority of participants were able to distinguish between the 2 species of loris and reported the provinces from which they believed animals were sourced for trade. Sellers in Phnom Penh reported that these provinces had large protected areas and, were located within the presently known distribution ranges of each species; this information corroborated with field survey data (Starr et al. 2010, in press). Opportunistic observations of 52 dried lorises for sale were made in marketplaces located near protected areas, indicating the lack of wildlife protection and conservation education in and near the protected areas. Strong enforcement of wildlife protection laws is required here to reduce and/or eliminate the supply of lorises to meet urban demand.

We found a sustained price increase over a 10 yr period for both species of loris, with the steepest increase occurring in 2006 (USD 9.39) to 2007 (USD 14.20), possibly indicating that the supply of lorises did not meet the demand. This might be the result of overexploitation, reducing the population size and hence harvest (Wilkie \& Carpenter 1999), and/or increased enforcement initiatives in the capital city. However, field surveys of lorises have 
indicated high hunting pressure in recent years, and subsequent population decline in Cambodia (Starr et al. 2010). Pygmy lorises had a consistently higher market value than northern slow lorises and were reported by sellers to be more potent, indicating the preference of using the former.

Supply chain data indicate that traders make a small profit per animal. The mean price of a pygmy loris in Phnom Penh in 2007 was reported as USD 14.20, and hunters reported to receive a mean of USD 5.92 in Mondulkiri Province; therefore, it can be assumed that the difference of USD 8.28 would be divided between traders and end sellers. In the case of the northern slow loris, this sum would amount to USD 5.86. Trading lorises either in large numbers or in conjunction with other wildlife of a higher market value would make them more profitable to traders and end sellers. Nevertheless, bearing in mind that the gross national income in Cambodia is USD 540 per capita per year (https:// www.cia.gov/library/publications/the-world-factbook/), even USD 4.00 per loris could contribute substantially to household income.

Sellers attributed price increases firstly to stricter law enforcement in Phnom Penh, and secondly to a reduction in loris numbers in the wild. However, interviewees in the Central Cardamom Protected Forest reported that the northern slow loris was thought to have become locally extinct due to high hunting pressure in the area, and field surveys in these sites have detected very low encounter rates, with no lorises detected on most transects (Starr et al. in press). In a separate study (Starr et al. 2010) population decline of pygmy lorises as a result of high hunting pressure has also been reported throughout Mondulkiri Province.

As is the case in many parts of the tropics, the influx of new technologies into the area has had a direct impact on the decrease in wildlife numbers (Laurance et al. 2006, van Vliet \& Nasi 2008). Local people reported increasing access to technology, such as longlasting spotlights and torches, in rural parts of Cambodia (Starr et al. 2010). Whilst lorises are likely to have long been used for traditional treatments (Ridley 1900), it is unlikely that off-take would be so high without the aid of modern technology. Historically, lorises might have been captured opportunistically when trees were felled (Baird 1993), but their characteristic eye shine and tendency to freeze when detected makes them the perfect targets for hunters armed with bright torches (Nekaris \& Bearder 2007). In other studies, arboreal nocturnal mammals were easily spotlighted, but their small size made them a less desirable catch for subsistence hunters (Laurance et al. 2008). In Cambodia, the high demand for lorises in traditional medicines means that lighting technology is a serious threat.
The reported primary uses of lorises for traditional medicines were consistent across Phnom Penh and provincial areas. Given the reported reluctance to use alternatives to loris medicines, our study shows that increased access or a reduction in costs of alternative therapies might not be useful strategies for conservation of lorises, a tendency also identified in other studies on traditional medicine use (Cunningham 1991). Primary users were identified to be wealthy to middle class women in urban areas, and the cost of alternative therapies is unlikely to affect their choice of medicines. Interview data supported these findings, with participants in Mondulkiri Province reporting that animals were traded, rather than used locally due to an ever increasing value of pygmy lorises. Combating the strong reluctance of users of traditional medicine in Asia to turn to Western therapies will be a key focus for future conservation efforts (Lee et al. 1998).

It is thought that a wildlife population can be harvested sustainably if the rate of off-take is lower than the rate of population increase (Robinson \& Bennett 2004). Slow lorises have some of the slowest rates of population increase among mammals of similar body size due to their long gestations, small litter size, low birth weights, long lactation periods and a long interval between births (Rasmussen 1986, Izard \& Weisenseel 1989). The increasing demand for loris products highlights the alarming risk of extinction and the urgency for immediate action to prevent this process; indeed, extinction seems already to be underway for Cambodia's northern slow loris population. We conclude by recommending that education and law reinforcement strategies developed from our data be used in a conservation programme for slow lorises involving collaboration between government and non-government organisations, particularly the NCTM and ATM.

Acknowledgements. We thank S. L. Pheng and P. Sok for locating traditional sellers and conducting the questionnaire within the capital city for this study. S. Chhun, S. E. Eam, S. Orn and S. Prak assisted with provincial interviews. We thank H. Punley, director of the National Centre for Traditional Medicine, L. Sothy, traditional practitioner and member of the Association of Traditional Cambodian Medicine, and U. Ton, CARE International health post manager, for their input. For hospitality and logistical support, we are grateful to the Wildlife Conservation Society, Conservation International, Flora and Fauna International and World Wide Fund for Nature-Cambodia programmes for supporting this study. Thanks to the Forestry Administration and the Ministry of Environment for permission to work in the sites. Thank you also to N. Marx from the Wildlife Alliance Mobile UnitCambodia, who provided confiscation data for this paper. Human ethics approval for this project (Approval number: 2006000222) was approved by the University of Queensland Behavioural and Social Sciences Ethical Review Committee. 


\section{LITERATURE CITED}

Alves R, Rosa I (2005) Why study the use of animal products in traditional medicines? J Ethnobiol Ethnomed 1:5

Baird I (1993) Logging and lorises in Cambodia. IPPL News 20:19-20

> Cheung SM, Dudgeon D (2006) Quantifying the Asian turtle crisis: market surveys in southern China, 2000-2003. Aquat Conserv Mar Freshw Ecosyst 16:751-770

Corlett RT (2007) The impact of hunting on the mammalian fauna of tropical Asian forests. Biotropica 39:292-303

Cunningham AB (1991) Development of a conservation policy on commercially exploited medicinal plants - a case study from southern Africa. In: Heywood V, Synge H, Akerele O (eds) Conservation of medicinal plants. World Conservation Union, Washington, DC, p 337-357

Izard MK, Weisenseel K (1989) Comparative reproduction of the Lorisidae. Am J Primatol 18:140

> Laurance WE, Croes BM, Tchignoumba L, Lahm SA and others (2006) Impacts of roads and hunting on central African rainforest mammals. Conserv Biol 20:1251-1261

Laurance WE, Croes BM, Guissouegou N, Buij R, Dethier M, Alonso A (2008) Impacts of roads, hunting, and habitat alteration on nocturnal mammals in African rainforests. Conserv Biol 22:721-732

Lee S, Hoover C, Gaski A, Mills J (1998) A world apart? Attitudes towards traditional Chinese medicine and endangered species in Hong Kong and the United States. TRAFFIC East Asia, TRAFFIC North America and World Wildlife Fund, Washington, DC

Martin E, Phipps M (1996) A review of wild animal trade in Cambodia. TRAFFIC Bull 16:45-60

Nekaris KAI, Bearder SK (2007) The strepsirrhine primates of Asia and mainland Africa: diversity shrouded in darkness. In: Campbell C, Fuentes A, MacKinnon K, Panger M, Bearder SK (eds) Primates in perspective. Oxford University Press, Oxford, p 24-45

Nekaris KAI, Nijman V (2007) CITES proposal highlights rarity of Asian nocturnal primates (Lorisidae: Nycticebus).

Editorial responsibility: Alan Dixson, Wellington, New Zealand
Folia Primatol 78:211-214

Rasmussen DT (1986) Life history and behaviour of slow lorises and slender lorises. PhD thesis, Duke University, Durham, NC

Rawson B, Roos C (2008) A new primate species record for Cambodia: Pygathrix nemaeus. Cambodian J Nat Hist 1:7-11

Ridley HN (1900) On the use of the slow loris in Malay medicine. J Straits Branch R Asiatic Soc 34:31-34

Robertson S, Thuong HV, Nguyen NN, Ho L and others (2004) The illegal wildlife trade in Quang Nam Province: covert investigations by specially trained forest rangers. Rep No. 5. The Quang Nam Forest Protection Department and WWF Indochina, Vietnam

Robinson JG, Bennett EL (2004) Having your wildlife and eating it too: an analysis of hunting sustainability across tropical ecosystems. Anim Conserv 7:397-408

Starr CR, Nekaris KAI, Streicher U, Leung LKP (2010) Field surveys of the threatened pygmy slow loris (Nycticebus pygmaeus) using local knowledge in Mondulkiri Province, Cambodia. Oryx 44 (in press)

Starr CR, Rogers L, Nekaris KAI, Streicher U (in press) Surveys and preliminary field observations of the northern slow loris (Nycticebus bengalensis) in Cambodia. In: Nadler T, Rawson B (eds) Conservation of primates in Indochina, Hanoi

Stich I, Krüger KO (2002) Artenschutz in Kambodscha. ZGAP Mitt 18:7-9

van Vliet N, Nasi R (2008) Hunting for livelihood in northeast Gabon: patterns, evolution, and sustainability. Ecol Soc 13:33-50

Walston N (2005) An overview of the use of Cambodia's plants and animals in traditional medicine systems. TRAFFIC Southeast Asia-Indochina, Phnom Penh

WB (World Bank) (2005) Going, going, gone: the illegal trade in wildlife in east and southeast Asia. World Bank, Washington, DC

Wilkie DS, Carpenter JF (1999) Bushmeat hunting in the Congo basin: an assessment of impacts and options for mitigation. Biodivers Conserv 8:927-955

Submitted: August 3, 2009; Accepted: April 9, 2010 Proofs received from author(s): June 1, 2010 